\begin{tabular}{c} 
Volume and Issues Obtainable at Center for Sustainability Research and Consultancy \\
Sustainable Business and Society in Emerging Economies \\
ISSN: 2708-2504 ISSN (E) 2708-2172 \\
Volume 1: No. 2, December2019 \\
ᄃSRᄃ \\
Journal homepage: www.publishing.globalcsrc.org/sbsee \\
\hline
\end{tabular}

\title{
Need for a University Start-up Framework for Commercialisation of Intellectual Property Rights (IPR): A Malaysia Perspective
}

\author{
${ }^{1}$ Noor Hidayah Shahidan, ${ }^{2}$ Ahmad Shaharudin Abdul Latiff, ${ }^{3}$ Sazali Abdul Wahab \\ ${ }^{1}$ Putra Business School, Serdang, Malaysia. hidayah.shahidan@gmail.com \\ ${ }^{2}$ Putra Business School, Serdang, Malaysia. shaharudin@putrabs.edu.my \\ ${ }^{3}$ Putra Business School, Serdang, Malaysia. sazali@putrabs.edu.my
}

\section{ARTICLE DETAILS \\ History \\ Revised format: November 2019 \\ Available Online: December 2019}

\section{Keywords \\ University Start-up, \\ $R \& D$ Commercialization, \\ Intellectual Property Rights, \\ Malaysia}

\section{JEL Classification:}

I23, I29, O34

\begin{abstract}
Purpose: There is only 8\% of Intellectual Property Rights (IPR) produced by the universities in Malaysia is being commercialized, therefore there is a need to increase the success rate of university start-up for sustainable income's generation by the universities. The aim of this paper is to review the need for a university start-up framework especially for Malaysian universities, which would facilitate the commercialization initiatives.

Design/Methodology/Approach: Review of literatures, which was comprised of articles in the field of management, technology transfer, social and behavioral sciences as well as reports from Malaysian government agencies and commercialization policies of 11 Malaysian universities. Qualitative content analysis method was used to analyze the commercialization policies by 11 Malaysian universities.

Findings: This paper reviews issues and challenges of IPR commercialization from the perspective of academic researchers and industry, issues related to university start-up in the context of Malaysia, and the need for a university start-up framework for commercialization of IPR.

Implications/Originality/Value: This paper is amongst the first to highlight on the issues of university start-up as a commercialization vehicle in the context of Malaysia.
\end{abstract}

(C) 2019 The authors, under a Creative Commons AttributionNonCommercial 4.0

Corresponding author's email address: hidayah.shahidan@gmail.com

Recommended citation: Shahidan, N. H., Abdul Latiff, A. S. and Abdul Wahab, S. (2019). Need for a University Start-up Framework for Commercialisation of Intellectual Property Rights (IPR): A Malaysia Perspective. Sustainable Business and Society in Emerging Economies, 1(2), 123-134

DOI: $10.26710 /$ sbsee.v1i2.1112

\section{Introduction}

In recent years, the creation and application of knowledge through science and technology have become one of the most crucial ingredients that drive national and economic developments. Malaysia, mainly, along with other developing countries, adopt the knowledge-based economy by putting more attention towards local university's Research and Development (R\&D) projects to propel the country's growth. To drive commercialisation, the government of Malaysia has allocated a significant amount of budget to 
propel R\&D and commercialisation, especially universities and other research institutions for the past 20 years. MOSTI Innovation Report (2016) highlighted that the National Action Plan for Industrial Technology Development was first introduced in 1991 to promote industrial-technological development. Since the 6th Malaysia Plan (1991-1995), strenuous efforts in commercialisation have taken place, followed by the 7th, 8th, and 9th Malaysia Plan. Under the 9th Malaysia Plan (2006-2010), a total of RM 3.101 billion has been invested in the form of R\&D grants, followed by RM 741 million for R\&D under the 10th Malaysia Plan (2011-2015) (Ali et al., 2017).

Even though the growth of patent applications for Malaysia has been rather phenomenal, the success rate of universities commercialisation has been very low. This scenario indicates that the fundamental idea of transforming universities' R\&D into commercial products/services has not been producing fruitful outcomes. Most of the research universities in Malaysia are already have their own technology transfer offices (TTO) being set up for the past ten years to manage IPR transfer from university to industry particularly. However, despite various attempts by the university management, the success rate of IPR commercialisation in comparison to the numbers of IPR generated is practically still very low. Between January 2013 and December 2018, Malaysia recorded a total of 282,825 applications of IPR filings. During the same period, MyIPO had approved a total of 215,036 IPR registrations (KPDNHEP, 2019). In contrast, despite high numbers of IPR being registered which mainly from the universities, commercialisation rate of publicly funded projects was only 5.1\% (6th and 7th Malaysia Plan), 3.4\% (8th Malaysia Plan) and 8\% (9th Malaysia Plan) (Malaysia STI Indicators Report, 2016).

This paper highlights the need for a university start-up framework for IPR commercialisation in the context of Malaysia. We first briefly defined the meaning of IPR, methods of IPR commercialisation commonly practised in Malaysia, followed by a definition of university start-up. Subsequently, we reviewed the issues and challenges from the perspectives of academic researchers and the industries in commercialisation of R\&D innovations based on commercialisation landscape in Malaysia. This paper then highlights the start-up phenomena in Malaysia, which also has influenced the universities to set up their accelerators and incubators to grow start-ups/spin-off companies. Next, we also summarised on the commercialisation and IP policies for 11 Malaysian public universities made accessible for public viewing, and also on other issues revolving university start-ups in Malaysia. Lastly, we concluded on the need for a framework for Malaysian university start-ups, which would facilitate the commercialization initiatives.

\section{Literature Review}

\subsection{Intellectual Property Right Commercialisation}

\subsubsection{Definition of Intellectual Property Right (IPR)}

In university commercialisation, the most focal asset to be brought to the market for it to have commercial value is an Intellectual Property Right (IPR). World Intellectual Property Organisation (WIPO) is an agency under the United Nations (UN) established in 1967 to encourage creative intellectual activity and for facilitating intellectual property around the world. WIPO (2015) describes the definition of IPR as:

"Intellectual property rights refers to creations of the mind: inventions; literary and artistic works; and symbols, names and images used in commerce"

According to WIPO (2015), intellectual property is categorized into two types:

- "Industrial Property includes patents for inventions, trademarks, industrial designs, and geographical indications"

- "Copyright covers literary works (such as novels, poems, and plays), films, music, artistic works (e.g., drawings, paintings, photographs and sculptures) and architectural design. Rights related to copyright include those of performing artists in their performances, producers of phonograms in their recordings, and broadcasters in their radio and television programs" 


\subsubsection{Methods of IPR Commercialisation}

In the business context, commercialisation refers to a series of actions for bringing innovation or a new product to the market (Datta et al., 2013). Commercialisation of IPR can concur as a series of actions for bringing new inventions with a novel, legally protected creations into the market via a company, partnership, or temporary organization with a defined business model. Based on Intellectual Property Commercialisation Policy for Research \& Development (R\&D) Projects Funded by the Government of Malaysia (2009), there are four types of commercialisation options commonly practised in Malaysia. In this context, the term "Recipient" refers to any person (s) or organisation who receives funds from the relevant government bodies to conduct $\mathrm{R} \& \mathrm{D}$, which resulted in the generation of IPR. In summary, the commercialisation options are licensing, assignment, the establishment of a spin-off company, and the creation of a joint venture company.

1. Licensing

- There are a few types of licensing, such as exclusive license, non-exclusive license, sole license and cross-license. Based on a licensing contract, the licensing arrangement is restricted by geographical locations, industry, time and domains of application.

- Exclusive License - the licensee has all rights of using the IP transferred by the recipient (the previous owner of the IP), in which the recipient is no longer able to exploit the IPR himself or to grant any license to another party. In this case, the recipient should be able to keep the rights to use for further R\&D and apply the IPR only for non-commercial use.

- Non-exclusive License - the recipient may award the rights of using the IPR for commercial purposes to one or more parties and retains the right to exploit the IP himself. In a nonexclusive license, the recipient may grant the licensee the rights to sub-license the IPR.

- Sole License - the recipient transfers all rights of exploitation of the IPR to the licensee but still retains his right to use the IPR himself.

- Cross-License - this licensing permits two or more IPR owners to authorise each other to exploit their IP for commercial and non-commercial purposes based on a written contract agreed by all parties. In a cross-licensing, the rights given by one party is a reciprocal grant of rights by the other. If the right transferred by the parties involved is not equivalent in value, payment for licensing fee or royalty can be included in the cross-licensing terms agreement.

2. Assignment - the recipient allows for a complete transfer of ownership to another party (assignee).

3. This type of commercialisation involves the outright sale of IPR rights to the assignee.

4. Spin-off company - the recipient, in which the owner of the IPR starts a company for IPR commercialisation, where inventor (s) and the recipient may own equity in the company together with a third party.

5. Joint venture company - the recipient launches a company with a third party for the commercialisation of the IPR, where the third party and the recipient are shareholders of the company.

\subsection{Definition of university start-ups}

Steve Blank (2013) defined a start-up as a company, a partnership, or a temporary organization intended to search for a scalable and repeatable business model. The term start-up was previously used to describe each type of new business or venture, in which a new firm was called a 'start-up'. Today, in certain countries and contexts, the term 'start-ups' refers to a special type of new firm or set up that mainly aims to develop new innovative business models that can be repeatable and scalable around a new service or product. A start-up keeps on testing and pivoting their business models until it can be up-scaled with a sustainable business model (Katila et al., 2012; Robehmed, 2013). The failure rate of start-ups is very high, and most of them failed, even though some start-ups have developed into large and prominent firms. Therefore, start-ups must deal with high risk, especially in terms of finances (Griffith, 2014). A new firm created specifically to market the technology invented in the university's laboratory is termed as "university start-up" (Harmon et al., 1997). The start-up licensed IP on technology from the university's 
laboratory to an entrepreneur who can launch the start-up (Siegel and Phan, 2005). In this case, the university researcher could be the entrepreneur who founds the start-up, or they could serve as a technical consultant or even be on the board of directors. There are circumstances where the faculty members can have an equity stake in the start-up company (Siegel et al., 2003).

The main focus of university start-up creation is as a feasible commercialisation vehicle for unverified technologies and to encourage the participation of investors to explore commercialisation viability of technologies from the university (Baycan \& Stough, 2013). In a university start-up, the entrepreneurs play a vital role in ensuring the dissemination of the knowledge deriving from the university (Fontes, 2005). In some scenarios, by creating a university start-up, the founders can validate the technology by conducted early market research to validate the commercial viability of that technology. The spin-off process involves an idea phase, a pre-start phase, a start-up phase, and a post-start-up phase. In this process, the development of the start-up founders and team intertwines with the life cycle of the venture. A dynamic, harmonious team will increase the probability of survival of the start-up (Clarysse \& Moray, 2004). University start-up is also an effective platform to attract investors to invest in pre-commercialisation stage of technology commercialisation.

\subsection{Issues and Challenges in IPR Commercialisation in Malaysia}

\subsubsection{Issues and Challenges from the Perspectives of Academic Researchers}

In the past ten years, research works on Malaysian universities commercialisation have been progressively conducted from time to time. Heng et al. (2012) conducted an exploratory study and conducted structured interviews with interviewees consisted of academic researchers and entrepreneurs. The main focus of the study was to identify the knowledge determinants that affect the academic researchers' perception towards commercialisation, which were necessary for a successful entrepreneurial venture. Knowledge determinants studied were 'business,' 'market,' 'up-scale,' and 'diversity'. The core findings of the study concluded on the significance of integrating the strength of academic researchers in the scientific and technical areas with know-how on business practicality. However, Heng et al. (2012) also stated that the lack of collaborative knowledge between industries and universities had created a massive gap in collaborative efforts, therefore hindering commercialisation efforts.

Subsequently, Aziz et al. (2013) conducted an investigation on researchers' behaviour and profiles in terms of their research achievement (over five years), attributes, behaviour, and attitude. Data was collected using a self-administered questionnaire for 500 academicians from the private and public universities. The survey was primarily developed to explore the researchers' attitudes towards Research, Development, and Commercialisation ( $\mathrm{R}, \mathrm{D} \& \mathrm{C})$. In summary, the study suggested that the researchers need to be equipped with knowledge and understanding of commercialisation. Another paper by Khademi and Ismail (2013) conceptually outlined the success factor of university commercialisation outputs, namely researchers' perception, time, entrepreneurial team, networking, technology stage, funding, market research, and TTO (Technology Transfer Office). Jamil et al. (2015) also reviewed the role of technology parks and university incubators as one of the commercialisation tools.

A later study by Ismail et al. (2015) then further worked on a conceptual framework for a successful research product commercialisation by academic researchers. Data was collected by interviewing four academic researchers that were said to have productively commercialized their research products. This study discovered for commercializing research products, various approaches are used - which heavily dependent on types of R\&D products and goals of the researcher. From these four academic researchers, only one of them chose to establish a spin-off company. At the same time, the other three opted for a contractual agreement, licensing assignment, and joint venture/partnership with international companies. Ismail et al. (2015) also analysed components affecting IP commercialisation in Malaysian universities to establish a common framework. These components are (i) knowledge, skills and personal traits of the researcher; (ii) creation of idea (iii) development, packaging, and promotion of the research product (iv) commercialisation paths; (v) building competitive advantage in the market (vi) selecting a business 
partner (vii) nurturing relationship with a business partner, and (viii) facilities and support. Figure 1 shows a framework for sustainable research product commercialisation as proposed by Ismail and team (2015).

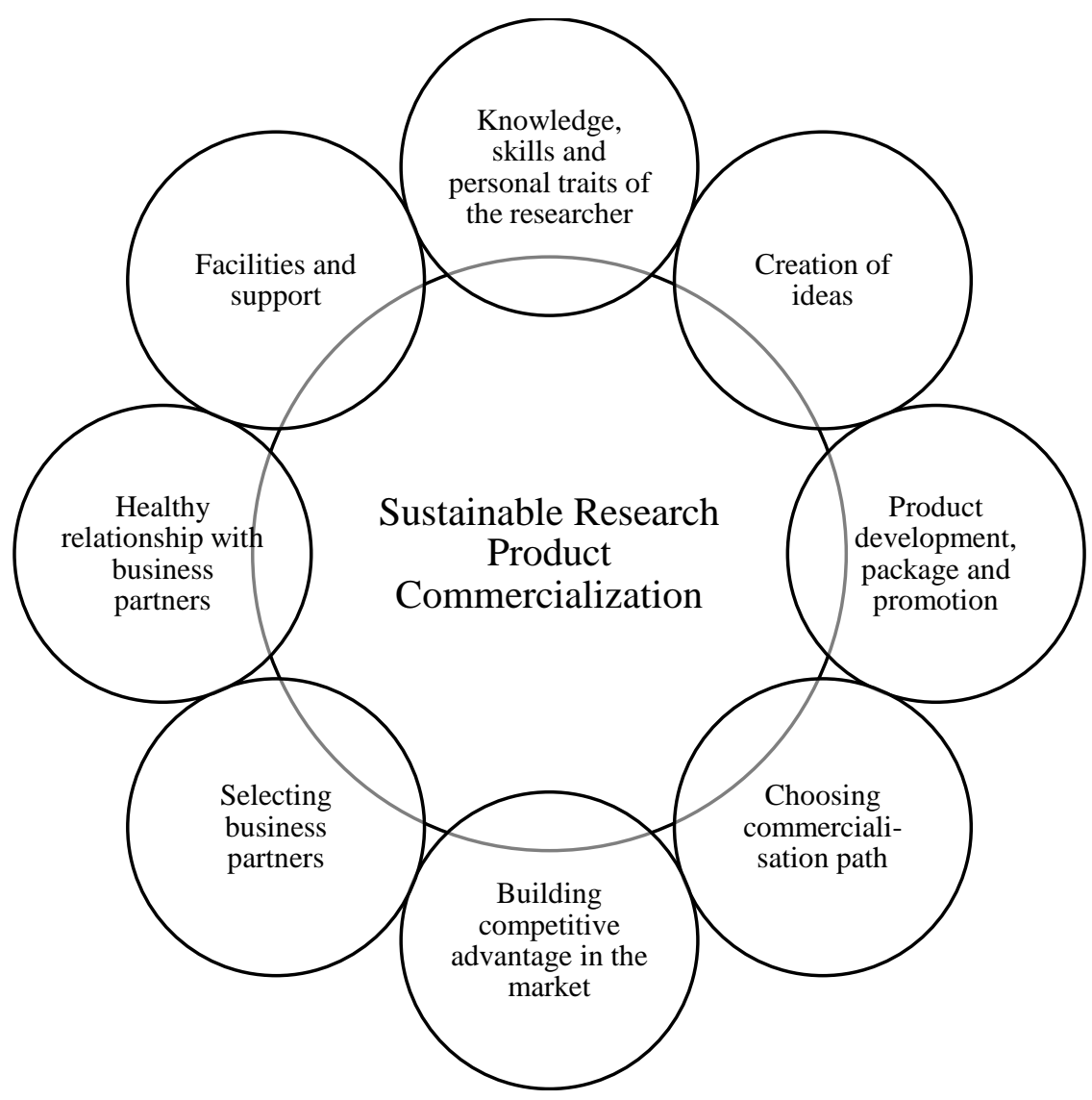

Fig. 1: A Framework for Sustainable Research Product Commercialisation (Ismail et al., 2015)

When comparing the study conducted by Ismail et al. (2015) with the study conducted by Latif et al. (2016), it is discovered that another element that should be incorporated into the framework that was previously developed is the entrepreneurial orientation (EO). Work by Latif et al. (2016) suggested that it was essential to incorporate EO to improve the rate of commercialisation of university R\&D products. The critical point of having EO is for the researcher to think like-wise like an entrepreneur. However, most researchers are bad entrepreneurs. Consequently, it is critical to match up a researcher with a skilful entrepreneur to bring the R\&D product to market.

From another perspective, Ismail and Mohamed (2016) mentioned that the most challenging factors in university $\mathrm{R} \& \mathrm{D}$ commercialisation are intellectual property protection policy and commercialisation policy. Research conducted by Ismail and Mohamed (2016) serves as a foundation to further explore issues related to IPR commercialisation from the perspectives of academic researchers. They conducted in-depth interviews with five researchers who have successfully commercialised their innovative researcher products. Critical findings of their study highlight commercialisation challenges from these three aspects: (i) intellectual property protection and commercialisation policy, (ii) development of innovative products with industrial demand, and (iii) gaps between academic researchers and industry collaborators.

\subsubsection{Issues and Challenges from the Perspective of Industry}

From the perspective of academic researchers, some industry collaborators only focus on making profits and neglecting to fulfil the responsibility to help the society (Ismail \& Mohamed, 2016). However, Ali et al. (2017) conducted a study to study in-depth issues related to the low commercialisation rate of 
university's R\&D products and successfully identified the problems contributing to low commercialisation rate of university IP from the industrial perspective. The respondents were Small and Medium Enterprises (SMEs) obtained from the SME Corporation website. Based on the surveys, 62.9\% respondents stated that the academic researchers lack effort to allocate sufficient time to maintain continuous contact with the industry, and they also claimed that the university R\&D products were considered obsolete by the industry $(55.5 \%)$. Besides, $66.6 \%$ of the respondents also agreed that university products were not ready to enter the market $(66.6 \%)$. Other than that, $51.8 \%$ of the respondents agreed that university products were highly technical and scientific, and not applicable to the existing system in the industry. Besides, $48.1 \%$ of the respondents claimed that the R\&D products by the universities were not unique as there were similar products readily in the current market. Based on the survey, the respondents also stated that they were not willing to invest in further R\&D of university products due to high cost and low investment return. The respondents also claimed difficulty in achieving agreement between the university and the industry on the amount of funding needed if further research works are required.

By evaluating from academic researchers and the industry perspectives, there is a huge gap between both worlds on the commercialisation of university IP, which contributed to the low success rate of bringing the R\&D products to the market, particularly through licensing, assignment, and creation of joint venture companies. This phenomenon is one of the contributing factors of why local universities are setting up accelerators and incubators to commercialise university IPR through the creation of start-ups.

\subsection{The way forward: Start-up phenomena in Malaysia}

In a nurturing start-up ecosystem, many stakeholders in the public sector play an active role in the start-up ecosystem - from matching funds to other initiatives like tax incentives and techno-entrepreneur programme development. Even though Malaysia is a relatively small country as compared to the neighbouring countries, it has been home for start-ups that managed to raise huge funding. iFlix raising US\$45 million in funding in March 2016 and kFit scoring US\$12 million in a Series A round. On the other hand, there is an example of a start-up that grows exponentially such as FlexiRoam and was managed to get listed in Australian Securities Exchange (ASX) in June 2015 (Malaysian Startup Ecosystem Report, 2016). Malaysia's start-up ecosystem is dominated by start-ups developing their technologies from IoT (Internet-of-Things) such as mobile apps and software in various industrial applications - smart city, agrotech, digital health, mobility, and clean energy (GES Malaysian Innovation Supercluster Report, 2017).

University start-ups, on the other hand, may also acquire IoT based technology from the university, but not limited to that. University start-up usually acquires technology IP from highly technical areas such as engineering, medical technology, biotechnology, and agriculture-based technologies. Public universities such as Universiti Putra Malaysia (UPM) and Universiti Malaya (UM) have set up their incubator hubs for home-grown IP commercialisation. UPM-Innohub was established in 2013 with start-ups taking up technologies on agriculture, biotechnology, food technology, ICT and engineering. UMXcellerate/UM Innovation Incubator was established in 2016 with the main focus on nanotechnology, oil \& gas, physical engineering, life sciences, ICT, and IoT. So far, these incubators have hosted 36 and 40 number of startups, respectively (Othman \& Jalaluddin, 2019).

\subsubsection{Issues Related to University Start-Up}

The creation of university start-ups encompasses a complex ecosystem involving various stakeholders from both academia and entrepreneurial. Technology transfer is a chronological process that requires adaptation and modification of the technology into something that is more market-fit compared to the original technology invented. There is a huge gap between laboratory demonstration or lab prototype and commercial utilization (Goldhor \& Lund, 1983). When the inventions are licensed to the start-ups, most of them are at the early stage of development. The invention is usually further refined during the early creation of the start-ups; therefore, the inventor's involvement in the process is essential. The start-up 
usually needs to agree to develop early-stage technology further. Since the technology may not be able to be in the market as soon as the start-up licensed the technology, instead of profiting the start-up from the beginning, the start-up might have to bear financial burden, especially if the licensing fee is high. Figure 2 shows the overlapping interaction of a university start-up between academia and the entrepreneurial world.

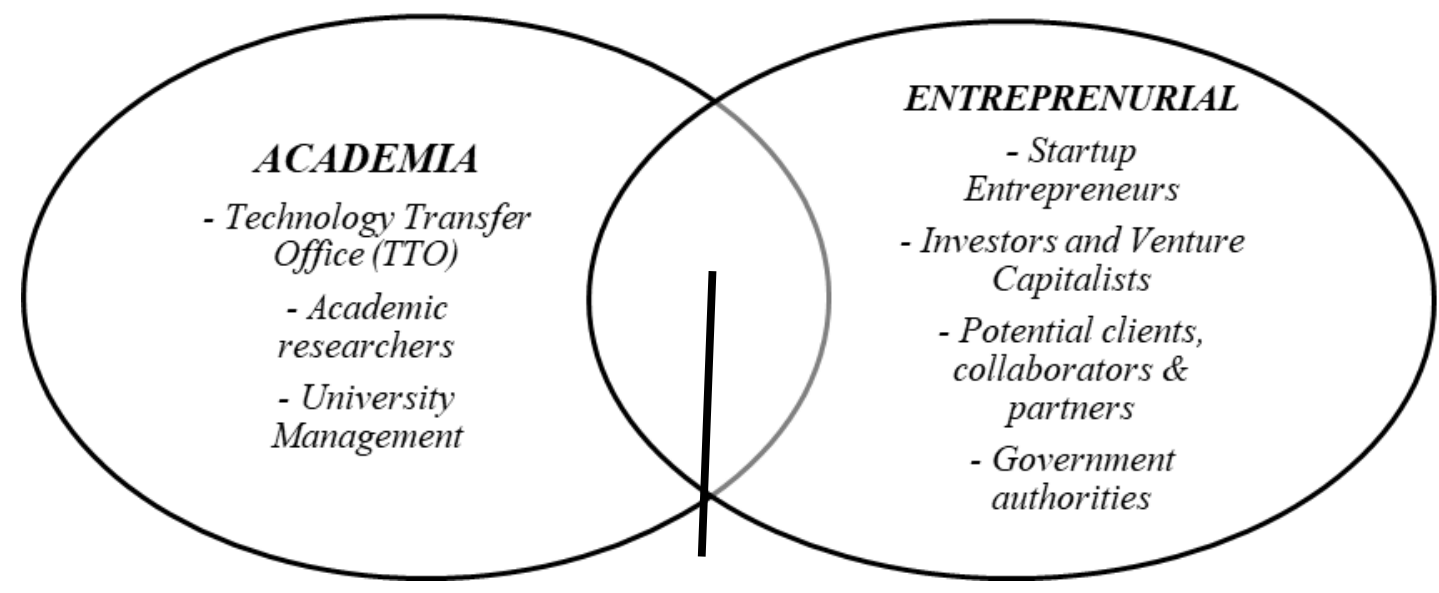

\section{University Start-up}

Fig. 2: The overlapping interaction of a university start-up between academia and the entrepreneurial world

In this section, we highlight the issues related to university start-up in the context of Malaysia.

\section{a. Lack of understanding of commercialisation concept and business-related knowledge by academic researchers}

While the main reason for start-up creation is to propel commercialisation of university innovations, understanding of commercialisation concept and readiness to commercialise amongst the academic researchers is one of the issues that should be taken into consideration for the generation of the framework. Work conducted by Ismail \& Mohamed (2016) highlighted a few important findings regarding academic researchers in understanding commercialisation. They found out that most researchers were not aware of the difference between commercialisation policy and intellectual property rights policy, and some of them were not even aware that they existed. Some of the researchers also were not willing to understand the flow of IPR applications, and some also did not know types of IPR to protect their innovation. Those academic researchers who have involved in the creation of a start-up company, on the other hand, think that they owned the company because they were the inventor of the IPR. In contract, the university actually owns the IPR. This situation indirectly correlates to the lack of business knowledge amongst the academic researchers, and ignorance on the responsibility as director and shareholder in a company according to Company Act 2016.

\section{b. Equity participation of academic researchers in university start-up}

There is always a debate on how much equity should academic researchers owned in a start-up as they are usually full-time employees working under the university. Ismail \& Mohamed (2016) stated that the researchers had gained so much when they can establish a start-up company, especially towards the end of the year Key Performance Index (KPI), in which the researchers will score high-performance index. Even though a few academic researchers formed start-up companies not for maximizing profits, there were other reasons, including technology improvement, financial enrichment, public service, skill enhancement, and career development. There were also more opportunities to access government grants by having a start-up as a platform (Hayter, 2011). There is also an issue regarding the licensing fee of the IPR. There is a concern on "double-dipping," especially by many venture capitalists that oversee the researchers enjoying both equity in the start-up as well as a vast portion of licensing fee. There are several 
concerns about the importance of establishing policies or guidelines when the universities established start-ups as commercialisation vehicles for $R \& D$ products. These concerns include equity participation as well as company directorship by the university, faculty, or individuals amongst the academic researchers. There should be policies implemented at a national level, especially for countries where the researchers are full-time employees at universities or research institutes (WIPO, 2015).

\section{c. Inconsistency of Commercialisation and Intellectual Property Rights policies for Malaysian universities}

Commercialisation Policy and Intellectual Property Right (IPR) Policy content from 11 public universities in Malaysia are compared and summarized (Table 1). These policies are accessible online for public viewing. By examining commercialisation and IPR policies of the 11 universities, similar contents concerning items as stated below are determined:

- Whether the policy defines the definition of IPR, the scope of IPR and ownership of the IPR

- Whether the policy states commercial exploitation of the IPR, description on types of commercialisation options, and action to be taken if the academic researcher wants to commercialise

- Whether the policy highlights on the amount of licensing fee and royalty to be paid by the licensee

- Whether the policy mentions the possibility of an academic researcher as a director in a start-up company and equity participation

- Whether the policy states in details role and responsibilities of an academic researcher as a director in a start-up company or only mention on this subject

- Whether the policy describes the conflict of interest and commitment in the commercialisation

- Whether the policy states how much equity of an academic researcher can have in a university start-up

The 11 universities are Universiti Putra Malaysia (UPM), Universiti Kebangsaan Malaysia (UKM), Universiti Sains Malaysia (USM), Universiti Malaya (UM), Universiti Malaysia Kelantan (UMK), Universiti Teknologi MARA (UiTM), Universiti Malaysia Pahang (UMP), Universiti Malaysia Sabah (UMS), International Islamic University Malaysia (IIUM), Universiti Teknologi Malaysia (UTM) and Universiti Tun Hussein Onn (UTHM). From Table 1, all of the universities have Item 1 to 5 described in their commercialisation and IP policies except for USM in which type of commercialisation options were not well defined in the policy. For all universities, information on licensing fees and royalty are stated in the policies (Item 6). However, not all universities stated any clause related to the involvement of university start-up or spin-offs, which is represented by Item 7, 8, 9, 10, and 11. While at least other universities did at least mention the commercialisation of IP via university start-ups as one of commercialisation options, this is not the case for UMS and USM.

In summary, most of the policies did not describe in detail the role and responsibility of academic researchers as a director in a start-up company and conflict of interest and commitment in commercialisation. These two points are vital as most of the time, the academic researchers are full-time employees at the university, which could primarily affect how much equity they could hold in a university start-up company. Based on Table 1, all policies on IP and commercialisation of each university did not mention specifically with justification on how much equity they could have in a university start-up. As there are other stakeholders in a company especially if the researcher teams up with a skilled entrepreneur to manage the start-up, this will be a strong determinant in ensuring the success of the university start-up. 
Table 1: Summary of Commercialisation Policy and Intellectual Property Right (IPR) Policy content from 11 public universities in Malaysia

\begin{tabular}{|c|c|c|c|c|c|c|c|c|c|c|c|c|}
\hline & Name of the University & UPM & UKM & USM & UM & UMK & UiTM & UMP & UMS & IIUM & UTM & UTHM \\
\hline & Summary of Policy Content & & & & & & & & & & & \\
\hline 1 & $\begin{array}{l}\text { This policy highlights on the definition } \\
\text { of Intellectual Property Rights }\end{array}$ & Yes & Yes & Yes & Yes & Yes & Yes & Yes & Yes & Yes & Yes & Yes \\
\hline 2 & $\begin{array}{l}\text { This policy describes the scope of IPR } \\
\text { \& ownership of the IPR }\end{array}$ & Yes & Yes & Yes & Yes & Yes & Yes & Yes & Yes & Yes & Yes & Yes \\
\hline 3 & $\begin{array}{l}\text { This policy explains on commercial } \\
\text { exploitation of IPR }\end{array}$ & Yes & Yes & Yes & Yes & Yes & Yes & Yes & Yes & Yes & Yes & Yes \\
\hline 4 & $\begin{array}{l}\text { This policy describes the type of } \\
\text { commercialisation in the form of } \\
\text { licensing, assignment, trade sales }\end{array}$ & Yes & Yes & No & Yes & Yes & Yes & Yes & Yes & Yes & Yes & Yes \\
\hline 5 & $\begin{array}{l}\text { This policy describes actions required } \\
\text { by academic researchers if they want to } \\
\text { commercialize their IPR }\end{array}$ & Yes & Yes & Yes & Yes & Yes & Yes & Yes & Yes & Yes & Yes & Yes \\
\hline 6 & $\begin{array}{l}\text { This policy highlights on the licensing } \\
\text { fee and royalty }\end{array}$ & Yes & Yes & Yes & Yes & Yes & Yes & Yes & Yes & Yes & Yes & Yes \\
\hline 7 & $\begin{array}{l}\text { This policy mentions the } \\
\text { commercialisation of IPR in the form } \\
\text { of start-up companies/spin-off } \\
\text { companies }\end{array}$ & Yes & Yes & No & Yes & Yes & Yes & Yes & No & Yes & Yes & Yes \\
\hline 8 & $\begin{array}{l}\text { This policy mentions of the academic } \\
\text { researcher as a director in a start-up } \\
\text { company and equity participation }\end{array}$ & Yes & No & No & Yes & Yes & Yes & Yes & No & Yes & Yes & Yes \\
\hline 9 & $\begin{array}{l}\text { This policy describes in detail role of } \\
\text { the academic researcher as a director in } \\
\text { a start-up company and equity } \\
\text { participation }\end{array}$ & Yes & No & No & Yes & No & Yes & Yes & No & No & Yes & Yes \\
\hline 10 & $\begin{array}{l}\text { This policy describes conflict of } \\
\text { interest and commitment in } \\
\text { commercialisation }\end{array}$ & Yes & No & No & Yes & No & Yes & Yes & No & No & Yes & No \\
\hline 11 & $\begin{array}{l}\text { This policy states how much equity of } \\
\text { a university/academic researcher can } \\
\text { have in a university start-up company }\end{array}$ & No & No & No & No & No & No & No & No & No & No & No \\
\hline
\end{tabular}

Notes: UPM = Universiti Putra Malaysia; UKM = Universiti Kebangsaan Malaysia; USM = Universiti Sains Malaysia; UM=Universiti Malaya; UMK = Universiti Malaysia Kelantan; UiTM = Universiti Teknologi MARA; UMP = Universiti Malaysia Pahang; UMS = Universiti Malaysia Sabah; IIUM = International Islamic University Malaysia; UTM = Universiti Teknologi Malaysia; UTHM = Universiti Tun Hussein Onn Malaysia

\subsection{The Need for a University Start-up Framework for Commercialisation of Intellectual Property (IP): A Malaysia Perspective}

As the purpose of a university start-up creation is to propel IP commercialisation, there is a need for a comprehensive framework to increase the success of a university start-up to develop into a scalable and sustainable company eventually. Currently, there is no framework or guidelines, which can be used as a template to facilitate university commercialisation through start-ups or spin-off companies based on findings from the literature that we have presented in the previous sections. This framework will:

- Improve the knowledge and understanding of academic researchers on intellectual property commercialisation and acknowledge the creation of a university start-up as one of the options 
- Improve the understanding and awareness of academic researchers on the risk and responsibility as a company director and shareholder according to the Companies Act 2016 (CA 2016) as well as general business-related knowledge

- Remove misconception and misunderstanding amongst the academic researchers in thinking they own the company because they are the inventor of the IPR

- Facilitate the university start-up in negotiating with Technology Licensing Office (TTO) in term of the amount of licensing fee and royalty based on the value of the IPR

- Enable start-up entrepreneurs to be cautious of legislative matters and prepare them with the required knowledge to defend themselves

- Facilitate university management to formulate comprehensive policies for both Intellectual Property Rights and Commercialisation

\section{Conclusion}

In summary, this review highlights issues and challenges on the low commercialisation rate of university $\mathrm{R} \& \mathrm{D}$ commercialisation in Malaysia. This paper also reviewed issues related to the creation of university start-ups and examined commercialisation and IPR policies for 11 universities in Malaysia. Last but not least, the framework will provide significant guidelines for various stakeholders in the commercialization of the technology innovation ecosystem in Malaysia. The stakeholders include, but not limited to, government agencies, venture capitalists, public and private universities, academic researchers, entrepreneurs and others involved in the commercialization of university R\&D products.

\section{References}

Ali, R., Leman, A., Mohamed, S. N., \& Ahmad, A. (2017). Issues Related to Low Commercialisation Rates of the University's Research and Development (R\&D) Products: Industrial Perspective. Advanced Science Letters. 23. 10616-10620. https://doi.org/10.1166/asl.2017.10114

Aziz, A. K., Harris, H., Zahid, S. \& Aziz, N. (2013). Commercialisation of University Research: An Investigation of Researchers' Behaviour. Communications of IBIMA. 1-19. https://doi.org/10.5171/2013.120942. 98-3

Blank, S. (2013). Why the Lean Start-Up Changes Everything. Harvard Business Review.

Baycan, T. \& R. R. Stough (2013), 'Bridging knowledge to commercialization: The good, the bad, and the challenging'. Annals of Regional Science. 50:367. https://doi.org/10.1007/s00168-012-0510-8

Clarysse, B. \& Moray, N. (2004). A Process Study of Entrepreneurial Team Formation: The Case of a Research-based Spin-off. Journal of Business Venturing. 19. 55-79. https://doi.org/10.1016/S08839026(02)00113-1

Datta, A., Reed, R. \& Jessup, L. (2013), "Commercialization of innovations: an overarching framework and research agenda", American Journal of Business, Vol. 28 No. 2, pp. 147-191. https://doi.org/10.1108/AJB-08-2012-0048

Fontes, M. (2005). The process of transformation of scientific and technological knowledge into economic value conducted by biotechnology spin-offs. Technovation. 25. 339-347. https://doi/10.1016/j.technovation.2003.08.004

GES Malaysian Innovation Supercluster Report, (2017) Accessed from MAGIC website: http://mymagic.my

Goldhor, R. \& R. Lund (1983), 'University-to-industry advanced technology transfer'. Research Policy 12 (3), 121-152. https://doi.org/10.1016/0048-7333(83)90015-X

Griffith, E. (2014). Why startups fail, according to their founders. Fortune Magazine, September, 25.

Harmon, B., Ardishvili, A., Cardozo, R., Elder,T, Leuthold, J., Parshall, J., Raghian, M., \& Donald, S. (1997), 'Mapping the university technology transfer process'. Journal of Business Venturing 12(6), 423-434. https://doi.org/10.1016/S0883-9026(96)00064-X

Hayter, C. (2011). In search of the profit-maximizing actor: Motivations and definitions of success from nascent academic entrepreneurs. Journal of Technology Transfer, 36(3), 340352. https://doi.org/10.1007/s10961-010-9196-1 
Heng, L. H., Rasli, A. M., \& Senin, A. A. (2012). Knowledge Determinant in University Commercialization: A Case Study of Malaysia Public University. Procedia - Social and Behavioral Sciences, 40, 251-257. https://doi.org/10.1016/j.sbspro.2012.03.187

Intellectual Property Commercialisation Policy for Research \& Development (R\&D) Projects Funded by the Government of Malaysia, MESTECC (2009) Retrieved from https://www.mestecc.gov.my/web/wp-content/uploads/2019/04/3.-Intellectual-PropertyCommercialisation-Policy-for-RD-English.pdf

Ismail, N., Nor, M. J. M., \& Sidek, S. (2015). A Framework for a Successful Research Products Commercialisation: A Case of Malaysian Academic Researchers. Procedia - Social and Behavioral Sciences, 195, 283-292. https://doi.org/10.1016/j.sbspro.2015.06.163

Ismail, N. \& Mohamed, K. (2016). Commercialising of Innovative Research Product in the Malaysian Public University: Challenges and Ways for Improvement. Research Journal of Business Management. 10. 1-14. http://doi.org/10.3923/rjbm.2016.1.14

International Islamic University Malaysia (IIUM) IIUM Policies and Guidelines for Intellectual Property Rights and Commercialisation Retrieved from http://www.iium.edu.my/

Jamil, F., Ismail, K. \& Mahmood, N. (2015). A Review of Commercialization Tools: University Incubators and Technology Parks. International Journal of Economics and Financial Issues. @BULLET. 10-11.

Katila, R., Chen, E. L., \& Piezunka, H. (2012). All the right moves: How entrepreneurial firms compete effectively. Strategic Entrepreneurship Journal. 6. 116-132. https://doi.org/10.1002/sej.1130

Khademi, T. \& Ismail, K. (2013). Commercialization Success Factors of University Research Output. Jurnal Teknologi. 64. 137-141. https://doi.org/10.11113/jt.v64.2284

KPDNHEP (2019), Key Note Speech YB Dato Seri Saifuddin Nasution during First IP and Innovation Researchers of Asia. Conference". Retrieved from https://www.kpdnhep.gov.my/kpdnkk/download/456/2019/25307/01022019_first-ip-iium-2.pdf

Latif, N. S. A., Abdullah, A., \& Jan, N. M. (2016). A Pilot Study of Entrepreneurial Orientation towards Commercialization of University Research Products. Procedia Economics and Finance, 37(16), 93-99. https://doi.org/10.1016/S2212-5671(16)30098-3

Malaysian Start-up Ecosystem Report (2016). Retrieved from http://mymagic.my

Malaysia STI Indicators Report (2016). Retrieved from https://mastic.mestecc.gov.my

MOSTI Innovation Report (2016). Retrieved from https://mastic.mestecc.gov.my

Othman, R. \& Jalaluddin, N. M. (2019). Bridging the 'gap'- Funding Solutions for the Future. A Malaysia Perspective. Asia Tech Monitor

Robehmed, N. (2013). What Is A Startup? Forbes Media \& Entertainment.

Siegel, D., Waldman, D., \& Link, A. (2003). Assessing the impact of organizational practices on the relative productivity of university technology transfer offices: An exploratory study. Research Policy, 32(1), 27-48. https://doi.org/10.1016/S0048-7333(01)00196-2

Siegel, D., \& Phan, P. H. (2005). Analyzing the Effectiveness of University Technology Transfer: Implications for Entrepreneurship Education. In G. Libecap (Ed.), Advances in the Study of Entrepreneurship, Innovation, and Economic Growth (pp. 1-38). (Advances in the Study of Entrepreneurship, Innovation, and Economic Growth; Vol. 16). https://doi.org/10.1016/S10484736(05)16001-9

Universiti Putra Malaysia (UPM) Commercialisation and IP Policy (2013) http://pendaftar.upm.edu.my Universiti Kebangsaan Malaysia (UKM) IP and Commercialisation Policy (2011) Retrieved from http://www.ukm.my/pik/ip-commercialisation-policy/

Universiti Sains Malaysia (USM) Intellectual Property Policy (2017) Retrieved from www.ico.usm.my

Universiti Malaya (UM) Intellectual Property and Commercialisation Policy (2014) https://umcms.um.edu.my

Universiti Malaysia Kelantan (UMK) Intellectual Property and Commercialisation Policy https://research.umk.edu.my

Universiti Teknologi MARA (UiTM) Commercialisation Policy (2018) Retrieved from https://ribu.uitm.edu.my 
Universiti Malaysia Pahang (UMP) Commercialisation Policy Retrieved from https://research.ump.edu.my/index.php/en/home/about-us/policy

Universiti Malaysia Sabah (UMS) Intellectual Property Policy (2014) Retrieved from https://www.ums.edu.my/ppiv2/files/C6.1-UMS-Intellectual-Property-Policy.pdf

Universiti Teknologi Malaysia (UTM) Commercialisation Policy (2014) Retrieved from http://www.icc.utm.my

Universiti Tun Hussein Onn Malaysia (UTHM) Polisi Hak Milik Harta Intelek (2011) Retrieved from http://rmc.uthm.edu.my

WIPO (2015) Accessed from https://www.wipo.int/portal/en/index.html 